\title{
ANALYSING 'TEACHERS' ROLES REGARDING CROSS-CURRICULAR COORDINATION IN CONTENT AND LANGUAGE INTEGRATED LEARNING (CLIL)
}

\author{
Víctor Pavón VÁzQuez \\ University of Córdoba \\ victor.pavon@uco.es \\ María del Carmen Méndez García \\ University of Jaén \\ cmendez@ujaen.es
}

\begin{abstract}
When analysing the main drivers for the success of Content and Language Integrated Learning (CLIL), interest has been paid to the significance of coordination between language teachers and content teachers to promote an effective integration of content and language. A decisive factor in teaching seems to be teachers' perception of their own professional identity, pedagogical standpoints, and performance. The aim of this study is to investigate their understanding of how CLIL influences content and language teachers' perceptions on the roles they take and on their own professional development. It endeavours to gain insight into CLIL teachers' opinions and their understanding of the importance of establishing coordination processes. The results obtained show that teachers believe that working in a CLIL programme benefits their professional profile, and that coordination between foreign language (FL) teachers and content teachers at different levels is fundamental.
\end{abstract}

Keywords: CLIL, perceptions, coordination, methodology, professional development. 


\title{
ANÁlisis de LOS ROLES DEL PROFESORADO EN LOS PROCESOS DE COORDINACIÓN TRANSVERSAL EN LA ENSEÑNAZA INTEGRADA DE LENGUA Y CONTENIDOS (AICLE)
}

\begin{abstract}
RESUMEN. Entre los principales factores que contribuyen a la efectividad del Aprendizaje Integrado de Contenidos y Lengua (AICLE), destaca la coordinación entre los profesores de la lengua extranjera y los profesores de las llamadas disciplinas no lingüisticas. Uno de los elementos decisivos de la práctica docente se encuentra en las propias percepciones que el profesorado tiene de su identidad profesional, posicionamiento pedagógico y actuación en el aula. El objetivo de este estudio es investigar las percepciones del profesorado con respecto a cómo AICLE influye en su desarrollo profesional y opiniones sobre la importancia de establecer una estructura de colaboración entre todo el profesorado implicado. Los resultados obtenidos muestran que el profesorado está convencido de que AICLE beneficia el desempeño profesional del profesorado y que la coordinación entre los profesores de lenguas y los de contenidos es fundamental para el éxito del programa.
\end{abstract}

Palabras clave: AICLE, percepciones, coordinación, metodología, desarrollo profesional.

Received 25 January 2017

Revised version accepted 22 March 2017

\section{INTRODUCTION}

The popularity of Content and Language Integrated Learning (CLIL) across Europe has escalated in recent decades (Marsh 2013). The rationale behind CLIL is that it is both possible and desirable to expand learners' linguistic competence in one or more additional language(s) through their use as vehicular language(s) in the teaching of selected content subjects (Coyle, Hood and Marsh 2010; Mehisto, Marsh and Frigols 2008).

In spite of this predominantly positive view, some critical voices have been raised against the 'CLIL frenzy'. Bonnet (2012: 66) states that the "added value of CLIL" needs to be questioned. In fact, in some contexts research confirms the negative effect of CLIL on learners' knowledge of content subjects and on their command of the language of instruction, partly attributed to the inappropriate input they receive from their teachers (Costa and D'Angelo 2011). For some, it is possible that the purported benefits of CLIL stem from external factors, such as the socioeducational background of CLIL students, rather than to CLIL tuition itself (Bonnet 2012; Bruton 2011, 2013; Costa and D'Angelo 2011). Even the consideration of CLIL as an umbrella term, encompassing "any learning activity where language is used as a 
tool to develop new learning from a subject area or theme" (Coyle, Holmes and King 2009: 6), has led others (Cenoz, Genesee and Gorter 2013, Cenoz 2015) to wonder whether there is any teaching or learning activity that does not fall within CLIL.

On the other hand, the outcomes of this approach have been covered extensively. CLIL allows the construction of content and language knowledge on the basis of semantic scaffolding (Lorenzo et al. 2009; Marsh 2009; Meyer 2010). Besides, CLIL learners are credited with a better mastery of oral registers (Berton 2008; Marsh 2007; Frigols 2008), particularly speaking (Coyle 2013; Lasagabaster 2008; Ruiz de Zarobe 2008, 2011), lexico-grammatical competence and pragmatic efficiency (Jexenflicker and Dalton-Puffer 2010; Lo and Murphy 2010; Lorenzo et al. 2009; Madrid 2011). Learners experience greater involvement in a more enjoyable environment (Coyle 2013) and, as a result, they are more motivated towards learning an additional language (Arnold 2011; Coonan 2012; Frigols 2008; Merisuo-Storm 2007; D'Angelo and García 2012; Ruiz de Zarobe 2013). CLIL is also said to contribute to broader educational objectives, such as critical thinking and intercultural learning (Méndez García 2013).

In terms of professional growth, CLIL creates an egalitarian atmosphere in which both teachers and students become co-experts in the additional language and cooperate to co-construct language learning and classroom interaction "while the technical content expertise remains with the teacher" (Hüttner, Dalton-Puffer and Smit 2013: 276). CLIL also boosts teachers' self-esteem and motivation by triggering "rethinking of their teaching vision" (D'Angelo and García 2012: 76). In this context, teachers' perceptions of their actual performance may significantly affect their understanding of the challenges that CLIL entails (Halbach 2009; Ramos Ordóñez and Pavón 2015), how to construct teacher collaboration (Meyer 2010), and how to scrutinise teachers' profile and competences (D'Angelo and García, 2012; Hylliard 2001; Pavón and Ellison 2013). A lot of attention then has been given to reviewing teachers' opinions of their role in CLIL and a number of studies have specifically investigated teachers' perceptions of CLIL in different European contexts (Hüttner et al. 2013 [Austria]; Infante, Benvenuto and Lastrucci 2009 [Italy]; Moliner 2013; Pena and Porto 2008; Travé 2013 [Spain]; Viebrock 2012 [Germany]).

This paper sets out to look into teachers' views of professional coordination. Coordination has been reported to produce positive results in English as a Second Language (ESL) and content-based instruction contexts (Creese 2010; Davison 2006; Tan 2011). In particular, this paper investigates teachers' opinions about the difficulties and benefits arising from collaboration between content and language teachers, and on the roles they take while establishing this coordinated work; it also analyses CLIL in their professional careers and, more specifically, how it influences their own academic and professional development. 


\section{TEACHERS' BELIEFS AND PERCEPTIONS OF THEIR PRACTICE}

Literature on teacher cognition acknowledges the need to carry out research on teachers' beliefs, although one of the main challenges it poses is the fact that beliefs are not directly observable (Borg 2006) and entail "accepting a proposition for which there is no demonstrable knowledge" (Woods 1996: 195). Beliefs are an important area in teacher cognition research because they enhance reasoning and assessing. Beliefs are closely related to constructs such as assumptions and knowledge, these three elements having been referred to as BAK (Woods 1996). Beliefs are further characterised by being propositions "consciously or unconsciously held", "evaluative in nature", "imbued with emotive commitment" and "a guide to thought and behaviour" (Borg 2001: 186). They lead to reflection on teaching and, therefore, pave the way for change: "without addressing teachers' pre-existing beliefs, changes cannot successfully be implemented in teacher attitudes or behaviour" (Hüttner et al. 2013: 269). Teachers' beliefs and perceptions of their own identity, the role they play in their institution and their pedagogical standpoints become a decisive factor in teaching (Tan 2011) and in how willing teachers are to embrace changes (Méndez García and Pavón 2012; Méndez García 2013). Despite the fact that it is difficult to establish a one-to-one correlation between beliefs and educational actions, teachers' self-perception and learning experiences seem to be at the heart of their decision-making processes and performance (Musanti and Pence 2010) because the way teachers see educational practices has an "enormous influence on the teacher's actions in the classroom" (Viebrock 2012: 78-79).

Research on beliefs and perceptions allows us to gain insight into students' motivation and experience, and into teachers' classroom behaviour (Hüttner et al. 2013). CLIL teachers' perception of their practice and their willingness to get involved in collegial participation are influenced by elements such as their expectations of support, their attitude to CLIL, the effort they put into the CLIL programme and the perceived achievements of CLIL tuition (Coonan 2007; Moliner 2013). Eventually, teachers' beliefs and practices are modified by students' performance (Bustos 2001; Pena and Porto 2008), which greatly contributes to teachers' overall perception of the outcomes of CLIL.

\section{CROSS-CURRICULAR COORDINATION IN CLIL ENVIRONMENTS}

An important characteristic of institutions providing CLIL education is the necessity for all stakeholders to coordinate and collaborate (Lorenzo and Moore 2010; Lorenzo, Trujillo and Vez 2011; Viebrock 2012). Particularly significant are the exchanges between language and content teachers since in the context of this study they are the ultimate agents responsible for planning, implementing 
and assessing the CLIL subjects. Davison (2006) sets the bases for content and language teaching co-operation as a process that requires:

- Conceptualising the task (planning, teaching and evaluating) so that content teachers are familiarised with the underlying principles of foreign language learning.

- Adopting a common curriculum (not just a common methodology and materials) in which the foreign language and the content-area curricula merge.

- Establishing goals and assessment. The incorporation of language goals into content subjects may be challenging because content teachers may not be aware of the language demands of their own area.

- Agreeing on the roles and responsibilities of teachers.

- Weighing diversity and L2 learning support.

- Reflecting on the tools for monitoring, assessment and feedback. (Davison 2006: 456-457)

A major step in coordination is agreeing on methodological and pedagogical foundations given that "pedagogies that are perceived as highly effective in the literature and used widely among language professionals (e.g., scaffolding, making links between form and function, noticing gaps in input, providing opportunities for negotiation) are perceived as less important than the content teachers' pedagogical practices" (Creese 2010: 101).

However, collaboration is not without its problems. It not only calls for external support and incentives, but also for internal resources, agreement on teaching loads, time to experiment, and relationship building (Davison 2006). The process of developing professional relationships with colleagues may cause anxiety, whereas trust may take some time to establish (Musanti and Pence 2010). Likewise, the methodological and pedagogical innovations associated with CLIL and the change in teaching patterns raises issues of control, personality clashes and resistance to advice (Hargreaves 1994). In spite of the difficulties inherent in collaboration and the initial resistance it is met with, co-operation constitutes a sine qua non of the teaching profession. It is only through peer exchanges that isolation is overcome, knowledge is co-constructed and beliefs in teaching are revisited (Musanti and Pence 2010).

\section{RESEARCH DESIGN}

\subsection{GOALS AND RESEARCH QUESTIONS}

The main objective of this qualitative study is to enquire into teachers' perceptions regarding the impact of CLIL on their professional development. It should be clarified, 
however, that this study looks into professed rather than enacted beliefs. It explores teachers' ideas on the potential influence of CLIL on their teaching practice and on the importance given to cross-curricular coordination. More specifically, coordination between teachers of an additional language and teachers of content, coordination between teachers of the content subjects, and coordination between the teachers of the language subjects are investigated. The possibility to set up a connection between the language that students learn as a vehicle of communication with the content they are learning favours a bi-directional relationship between the academic knowledge and the language needed to understand and express this knowledge. Moreover, this collaboration could be extended to other areas and include the coordinated work of content teachers, and also the coordination between the teacher of the language of instruction, the teacher of the mother tongue and the teacher of other languages present in the curriculum. Hence, a concurrent objective is looking into teachers' perceptions of the roles taken by language and content specialists in the CLIL programme. As a consequence, the research questions guiding this study are:

a) In what way does CLIL affect teachers' perception of their professional development?

b) How do content and foreign language teachers perceive and structure interdisciplinary coordination?

c) How do content teachers perceive and structure their own interdisciplinary coordination?

d) How do foreign language and first language teachers perceive and structure their own interdisciplinary coordination?

\subsection{CONTEXT AND PARTICIPANTS}

The study reported here has been conducted in Andalusia, a monolingual region in which the only acknowledged official language is Spanish. This study was carried out during 2012 in primary and secondary schools involved in the Plan to Promote Plurilingualism initiated in 2005 (Junta de Andalucía 2005). Plurilingual education is nurtured in a partial-immersion programme in which at least three of the subjects are taught through an additional language (generally English, but also French or German) considered as an "instrumental language, a language of learning, a teaching vehicle, which is used in parallel to the first language (the mother tongue). It does not, at any time, invalidate the first language" (Junta de Andalucía 2005: 18-19).

In this context, the teaching of content is exclusively carried out by content teacher specialists, with the exception of some cases in primary education, 
where the content teacher may also be a specialist in an additional language. Schools appoint a coordinator, usually a teacher of an additional language, who is responsible for coordinating the work of the teachers involved in the programme. There is also a language assistant, a native speaker who mainly collaborates with content teachers.

A total of 42 primary and secondary education teachers (27 content teachers and 15 language teachers, 18 teachers of primary education and 24 teachers of secondary education) from 25 state-run schools (10 primary and 25 secondary schools) participated in this cross-sectional study. The age of the participants ranged from 30 to 45, and around two thirds of the teachers were women (68\%). All of them were engaged in the Plan to Promote Plurilingualism (Junta de Andalucía 2005), and had received training and guidance on the principles of CLIL through conferences and workshops. This training enabled them to become familiar with CLIL curricular organisation, the creation of content and language integrated lesson plans, methodological strategies, adaptation and elaboration of materials, and assessment. It is important to note that the participants belonged to schools with an average experience of five years of implementation of the bilingual programme.

\subsection{INSTRUMENTS AND DATA COLLECTION}

A questionnaire with 25 questions (see the Appendix) was designed to both encourage teacher reflection and elicit quality-rich data on teachers' perceptions of their CLIL practice, but not specifically on their beliefs. With a view to obtaining qualitative data, all the questions formulated in the questionnaire were openended. The questionnaire was distributed online to 55 teachers participating in a professional development programme and teachers were invited to submit their answers within the course of one week. 42 teachers answered all the questions, a response rate of $76.3 \%$.

Data were analysed by identifying key ideas and emergent themes in the answers given to the questions. The authors labelled and analysed data independently and then worked together until they reached a joint agreement on the issues that emerged. The analysis of the data was based on the inductive approach of grounded theory proposed by MacKey and Gass (2005), by which the focus is on the emergent categories arising in the different stages of the analysis and not on pre-established categories. For example, the analysis of the data corresponding to research question 1 was codified according to two main emergent themes, teachers' perception of the skills CLIL education demands and the desirability or necessity to shift methodological practices. 


\section{RESULTS}

The data presented below has been grouped according to the research questions posited. The first sub-section addresses the teachers' understanding of how CLIL influences their personal development. The next three sub-sections delve into their perceptions on the collaboration process between content and foreign language teachers, between content teachers, and between language teachers ${ }^{1}$.

\subsection{ACADEMIC AND PERSONAL DEVELOPMENT}

Getting involved in a new educational initiative is always a challenge for teachers. Participating in CLIL requires a clear understanding of the aims and characteristics of the specific bilingual programme, and a solid knowledge of curricular organisation, strategies, techniques, and specific assessment procedures.

In the main, when it comes to analysing teachers' perceptions of their own personal and professional development, their opinions are overwhelmingly positive. They consider CLIL a rewarding and enriching teaching experience, and a medium to achieve intellectual improvement:

It is clearly enriching for me, both personally and professionally. (T2)

Making students progress intellectually contributes to our own global and intellectual development. (T3)

They state that the challenge of teaching content through an additional language is an exciting objective in their professional life, which incentivises and stimulates them, while acknowledging that it requires more effort:

The bilingual programme has changed the traditional attitude that we always feel at the beginning of the academic year; we have found a new stimulus in our work. (T39)

The motivation of students compensates for the effort that the teachers have to make everyday. (T10)

It is common to find views which emphasise that teaching becomes more motivating and that CLIL has brought about continuous training and adaptation to a different type of practice, which ultimately influences teachers' professional development:

\footnotetext{
1 Teachers' quotations are labeled with a T followed by a number from 1 to 42, the respondents' number.
} 
Teachers get more motivated because this is a new incentive for our professional routine. (T36)

In addition, teachers envisage CLIL as a way of expanding their professional development, which not only becomes "more global", but also promotes the incorporation of an intercultural perspective into education, and equips them to better understand and deal with diversity:

We have a richer and more global professional development, for example through contact with other European schools. (T32)

I think that bilingual programmes facilitate a more tolerant attitude towards diversity. (T36)

Most of these positive judgements derive from respondents' awareness of the methodological shifts CLIL calls for:

We are forced to renew our teaching habits, use new materials, teach differently, and assess using other criteria... All this benefits our professional performance day by day. (T14)

The necessity to overcome the difficulties of using an additional language demands the use of more varied resources and a wider capacity from teachers to create an effective learning environment. (T23)

They are well aware that they need to have a firm grasp of specific strategies and techniques, and consequently are prone to take part in continuous training activities:

Getting engaged in the bilingual project demands a continuous development of the teachers' competences in order to obtain positive results in our classes. (T37)

Finally, in spite of this overall positive perception, it cannot be denied that CLIL is challenging due to the necessity to invest a considerable amount of time and effort, and to the need to incorporate manifest methodological and pedagogical changes. Hence, it is not surprising that some may consider their engagement in CLIL a highly demanding experience:

Due to the necessary changes in my teaching performance, the elaboration of materials and the extra number of preparation hours, the personal burden, for example in my case, may be excessive. (T8)

Depending on our expectations, it may cause stress rather than intellectual development in certain teachers, especially older ones. (T32) 


\subsection{COORDINATION BETWEEN FOREIGN LANGUAGE TEACHERS AND CONTENT TEACHERS}

As stated above, the impact of a new educational paradigm on the respondents' perceptions and the need to make significant changes to their methodology are seen as decisive factors in the implementation of CLIL programmes. In this context, understanding that the additional language subject plays a pivotal role in CLIL, and helping students garner the linguistic competence necessary to assimilate academic content, is of paramount importance.

With regard to structuring coordination between the additional language teachers and content teachers, the target vehicular language as a subject plays a significant role in CLIL contexts as it aids the development of the specific academic language proficiency required in the content subjects. One of its functions is to stimulate fluency and to develop strategies to understand and verbalise academic content. In addition, the language as a subject acquires a new dimension in CLIL, since the traditional perception of learning a language as an independent subject has shifted to acceptance that it can be the medium for understanding the content of other areas. For many teachers, the assumption is that coordination between language and subject teachers is a basic premise beyond question:

Coordination between the FL teachers and the content teachers is the basis for successful teaching of content. (T39)

One of the functions of coordination between language and content teachers is to reach an agreement on the linguistic necessities that instruction through an additional language may require. Inevitably, this process might demand a partial restructuring of the language syllabus, which is occasionally adapted to allow for the anticipation of a particular linguistic element needed in the content class:

There should be a close collaboration between FL and content teachers. It is vital that both teachers agree on the linguistic needs of the students/learners or the linguistic demands of the content subject. (T18)

I think that support from FL teaching is fundamental. I cannot teach History if my students do not know how to use the past tense. (T9)

It is noteworthy that teachers are aware that this type of coordination has the potential to enhance a sense of integration and cross-curricular teaching, reinforces the collaborative dimension, and can benefit the whole school:

It is a fantastic measure because it obliges teachers to work as a team. (T4)

Coordination is essential in order to construct something stable, not only among the colleagues in the bilingual project, but also in general. (T41) 
In addition, teachers emphasise that it brings about methodological gains for both language and content teachers, and helps them develop their teaching strategies:

Working together will enhance the development of a more effective and participative methodology. (T22)

This coordination should be obligatory because getting to know the methodological strategies of both types of teachers may be very useful and tremendously beneficial. (T39)

The identification of teachers' roles in CLIL may be a source of disquiet for some professionals because it may be difficult to separate linguistic performance from knowledge of content and often content teachers are unsure about their role with respect to both. In the present study, the responses reveal the demand for a clear and well-structured assignment of roles. Respondents report that the language studied in the language classes should support content learning, to either or both anticipate and consolidate vocabulary, linguistic structures and functions:

FL teachers should support content areas by providing the foundations and language structures that content teachers have to use in their content materials. (T41)

It is essential that FL teachers help consolidate linguistic aspects by working on specific vocabulary used in content classes, consolidating the use of certain grammar structures and focusing on facilitating the comprehension of content material. (T37)

Common assessment criteria and instruments, specific attention to linguistic errors in the language classes and the recurrent argument for a shared methodological dimension constitute three further essential factors:

Coordination should go beyond anticipation of linguistic elements and cover procedures, selection of contents, and definition of assessment criteria and instruments. (T11)

I think it is necessary that FL teachers and content teachers reach a consensus about strategies and methodological principles. (T31)

Finally, views are expressed that it is important to coordinate a common use of everyday language both in the FL classes and in the content classes as a way of agreeing on models of usage in these two contexts:

It is really productive to work on specific vocabulary prior to teaching the content, but it would also be beneficial to focus on common use of the language in the FL class and in the content class. (T5)

However, it also significant that some respondents question the feasibility of successful coordination between language and content teachers and stress that time constraints constitute a major limitation: 
Coordination is impossible because of the incompatibility with our schedules. Also we have very little time available, a lot of bureaucratic work, reports, etc., too much extra work. (T30)

\subsection{COORDINATION BETWEEN CONTENT TEACHERS}

In general, teachers assume that coordination among content teachers is also beneficial per se and should be established:

This coordination is essential so that students can assimilate vocabulary and concepts with ease. No coordination, no benefits. (T2)

Coordination is at the very heart of the effectiveness of the programme. Without coordination we couldn't achieve positive results. (T5)

Teachers seem to agree that this coordination is likely to improve the understanding and processing of information, especially if there is thematic cohesion among the different subjects:

Working with shared and similar concepts in our content subjects makes the outcome of our teaching more fruitful. (T4)

All kinds of coordination are important, but this is even more necessary because it enables students to draw connections between the content of the different subjects. (T15)

The larger the number of interrelated vocabulary items and concepts addressed, the higher the possibility of facilitating comprehension and assimilation of content:

Coordination of content helps facilitate assimilation as students benefit from receiving interconnected academic material. (T21).

By working together, content teachers help students connect concepts from different areas. (T26)

Similarly, it is argued that coordination of content subjects not only facilitates the development of the language, but it is also a key process in consolidating a sense of connection among teachers, and the feeling that collaboration is enriching for both school and teachers:

It does not only benefit the assimilation of content, but working with similar concepts also supports the linguistic dimension. (T29)

It is not only a fundamental measure; it is also rewarding to establish links with your colleagues. (T8) 
ANALYSING TEACHERS' ROLES REGARDING CROSS-CURRICULAR COORDINATION IN CONTENT ...

We should use this coordination as a means to learn from our colleagues. (T12)

As with language-content teacher coordination, respondents also emphasise the importance of the methodological dimension in the coordination between content teachers, on the grounds that it is crucial for enabling quality education:

It would be desirable if we could use a common methodology. (T35)

Quality in education is also based on getting to know different kinds of teaching and choosing the best practices from each other. (T3)

Content teachers concur that promoting homogeneity in the use of teaching strategies, common techniques, and connecting and revisiting topics and concepts helps achieve better results:

Working together will allow us to plan common tasks to work on contents in an integrated way, and will additionally help us share ideas and strategies. (26)

Teachers must insist on exploiting the techniques of redundancy specifically in order to strengthen cohesion and interrelation of contents in the different subjects. (T33)

Further illustrative aspects are the importance of reaching a shared view on assessment, class management dealing with disruptive students, and establishing a solid collaboration with the families so that students can receive support at home:

I believe that we should also try to coordinate assessment criteria, classroom management and even attention to discipline problems. (T14)

I would suggest that it could be highly beneficial to collaborate with the families, so that parents can support their children's learning at home. (T34)

Although a consensus exists on the necessity and gains of this type of coordination to promote the assimilation of content material, there are also some concerns about its implementation, or at least about the difficulties that content teachers may encounter when coordinating their work. Indeed, some consider that it is hard for content teachers to coordinate their teaching, mainly due to the absence of resources and, once again, time constraints:

Even though this coordination is crucial to the success of the programme, in reality, conditions do not make it possible. (T30)

In practice, it is really difficult for content teachers to work together as the slots in their work timetables do not simply coincide. (T26) 


\subsection{COORDINATION BETWEEN FOREIGN LANGUAGE AND FIRST LANGUAGE TEACHERS}

The role of the other languages involved in CLIL is likely to be viewed as a way to support and consolidate the additional language and, by extension, the CLIL programme. Some respondents openly recognise the potential of collaborative relationships between language teachers:

To me, an integrated curriculum is based on the collaboration between teachers in all areas, and the coordination between language teachers is an area that should be explored. (T19)

The language subjects involved in bilingual programmes may facilitate the learning of content through these languages. Language teachers seem to be aware of this phenomenon and suggest a coordinated approach to improve language competences. Even for some this should be established prior to any other kind of coordination:

All language subjects promote the acquisition of learners' language competence and it seems obvious that this should be tackled in a coordinated way. (T28)

The first type of coordination that should be established is the coordination between the language subjects, and once this is established, we could move on to develop coordination in the other areas. (T34)

Working with common language functions and structures, and similar types of discourse and textual genres in the different languages may strengthen linguistic elements and the communication strategies which are necessary to understand and verbalise content material:

Working with similar language functions in the L1 and in the FL is highly beneficial for the two languages; students can compare the languages, which leads to a better language use of both of them" (T21)

It is important that we work on language functions, vocabulary, types of discourse and textual genres in the three languages (L1, FL and even a second FL). I think it is crucial in promoting metalinguistic reflection. (T22)

In addition, this collaboration transcends the language dimension as the knowledge and expertise provided by the different language teachers may have a positive impact on their understanding of the mechanisms that are necessary for the acquisition of languages. It may also foment a more communicative performance, and, consequently, improve the quality of their teaching:

In our school we are coordinating the use or common communicative functions in the mother tongue and in the FL and the results are fantastic. (T14) 


\section{DISCUSSION}

The data yielded in this study confirm that, as posited in research question (a), involvement in CLIL seems to influence teachers' thoughts about their own professional development. Even though teachers quite often experience a certain degree of discomfort that stems from the challenges arising from this innovative way of teaching and learning (Pavón and Rubio 2010), in line with other studies (Hüttner et al. 2013), a positive feeling is generally reported. CLIL teachers claim that, though difficult to put into effect, participating in CLIL leads to positive, rewarding, motivating and stimulating outcomes. Teachers believe that through CLIL they are more motivated and are actually becoming better professionals because of the necessity to participate in continuous training and adapt their materials and methodology to the new teaching and methodological requirements (Wolff 2012).

As to research question (b), on the supposed gains of coordination between language and content teachers, data indicate that, similarly to contexts where content-based instruction is utilised (Lo 2015), there are perceived benefits for students (who are said to improve their proficiency in the language of the CLIL class), and for content teachers (who benefit from a different use of teaching strategies and new methodological approaches). There is a necessity to define the roles of language and content teachers, as language teachers are often credited for providing linguistic support by anticipating and/or consolidating vocabulary, linguistic structures and functions. As to content teachers, a key question is whether they act solely as teachers of content material or if they also need to occasionally resort to linguistic explanations about the vehicular language. If the content teacher is also a language specialist this should not be an issue. However, when content teachers are only specialists in their subject(s) they may simply consult language teachers when they need clarification on linguistic aspects, as reported by Tan (2011) in studies conducted in content-based instruction contexts. On the other hand, CLIL teachers may foster a structure of collaboration in which language teachers, when required, adapt their language classes to the linguistic items and functions that students might need in the content classes (Pavón and Ellison 2013). Responses show that the role of the language is perceived as a fundamental support to content subjects because it helps expand learners' language proficiency. Ideally, in the language class, vocabulary, structures and functions should be connected to the cognitive and linguistic demands of content subjects. Finally, the benefits extend not only to academic use of the language (as in Cognitive Academic Language Proficiency) but also to everyday use of the language (Basic Interpersonal Communication Skills) (Cummins 1984, 2008).

As regards research question (c), coordination among content teachers, there is evidence that teachers find coordination relevant for the consolidation of content 
material, and advantageous for students, teachers and the school in general. According to Coyle et al. (2009) and Dale, Van der Es and Tanner (2010), success in CLIL largely depends on the establishment of coordination mechanisms among content teachers. Coordination among professionals in charge of different content subjects based on similar thematic areas, concepts, ideas and notions seek to facilitate the assimilation and consolidation of academic material and to reduce the difficulties of teaching through an additional language, an issue on which teachers concur. According to the data, connecting topics and using interrelated vocabulary and concepts in the different subjects is a productive means to help students understand and process content. Working with shared vocabulary and concepts in the content subjects has been reported to have a noticeable impact on connecting new and previously established concepts (Graaf, Koopman and Tanner 2012). However, professionals warn that content teachers' coordination needs to go beyond these factors and comprise agreement on methodology and teaching practices.

Finally, coordination among language teachers (question d) seems to yield some gains, according to the responses. When examining teachers' coordination in different contexts (Creese 2010; Davison 2006; Graaf et al. 2012), coordination between teachers of different languages has not received as much attention as coordination between language-content teachers, and content-content teachers. However, planning shared and common work on language functions may facilitate the cognitive development connected to the operation of interlinguistic processes, thus contributing to an acceleration of positive transference and consolidation of communication strategies between all the languages (Lorenzo 2013). In line with this idea, it seems reasonable that similar benefits can be reaped from coordination with the other languages present in the curriculum. This specific coordination may assist "the formation of a common linguistic capacity" (Pavón et al. 2014: 4). This coordinated work in the different language subjects may bring about important gains and play a significant part in facilitating the understanding and expression of academic content, which in turn may reinforce the processing and consolidation of academic material in the content subjects (Coyle 2015; Meyer et al. 2015). Research in this field reveals that collaboration between the first language teacher and the additional language teacher may be an effective strategy for supporting students' understanding of content (Dobson, Pérez and Johnstone 2010: 52). It is argued that joint work among language specialists enhances the cognitive processes and interlinguistic transference that ultimately leads to the consolidation of communication strategies in the different languages (Lázaro and García-Mayo 2012; Laupenmühlen 2012; Méndez García and Pavón 2012). Some of the advantages brought to the fore are the promotion of common cognitive processes, transference among the languages, 
and strengthening of shared communication strategies. Furthermore, verbalising content in different languages through the use of similar types of discourse and analysis of textual genres (narrative, descriptive, etc.) seems to improve common macro and micro linguistic structures (Lorenzo and Rodríguez 2014). Although language teachers' coordination is not frequently addressed in CLIL research, the teachers investigated state that selecting common linguistic objectives and contents, designing activities that require similar use of the language, and in general working with linguistic elements and communication strategies may have a distinct effect on CLIL.

\section{CONCLUSION}

Putting CLIL into practice is not an easy endeavour. In fact, there is no single recipe or standardised CLIL model because of the wide variety and enormous complexity of the factors that are involved (Marsh 2013). The success of CLIL rests on taking all important decisions and adequately deciding the procedures on an adequate selection of all-important decisions and procedures related to curricular organisation, the role of the different stakeholders, and pedagogy and materials, which makes it difficult to delineate a single model that can lead to specific outcomes (Cenoz et al. 2013; Mehisto and Genesee 2015). Among these variables and dimensions, following the perceptions of the teachers investigated and in line with studies on the same topic (Davison 2006; Graaff et al. 2012), coordination and collaboration between language and content teachers is perceived as a decisive constituent for the success in CLIL.

As perceived by teachers, CLIL becomes both a rewarding but highly challenging experience. It is through CLIL that practitioners strive to put into practise new methodologies to explore their subjects from different perspectives and in a more student-friendly way. Teaching their subjects through the CLIL language does motivate, stimulate and keep them updated; more importantly, it provides teachers with a sense of achievement. In this regard, coordination proves to be paramount. Content teachers need the support and expertise of foreign language teachers to make the most of their subjects. Foreign language teachers in turn incorporate a new dimension into their lessons, which are enriched by the necessity to link the language programme with the language and notions of the content areas they need to support. Finally, the collaboration between teachers of the mother tongue and foreign language is beneficial in their constant search for courses of action to improve students' language competences.

Consequently, CLIL demands a radical change of perspective in terms of the roles that teachers play. In general, their opinions confirm that the efficacy 
of this educational proposal requires the existence of a structure of connection, coordination and collaboration between all the stakeholders (Mehisto 2009, 2012), and especially, between teachers (Viebrock 2012). In CLIL, this proposition is really important because setting-up an organisational model based on coordination between subjects and the collaboration between teachers and team work may contribute notably to raise the standards in two different dimensions. First, coordination facilitates the learning and consolidation of academic content, and improves students' language proficiency (Lorenzo et al. 2011: 301). Secondly, coordination determines some important decisions that have to be taken by the school management team and "will be crucial for the organisation of the teaching and for the achievement of subsequent outputs" (Baetens-Beardsmore 2009: 210).

The participants in this study, all of them actively involved in Andalusian CLIL schools, concur that teachers involved in the bilingual programme need to redefine their roles and work in a coordinated and collaborative way. But their opinions need to be heard and ideally should influence schools and educational administrations, which have a key role to play in facilitating coordination. Hence, special conditions need to be set up to foment coordination and collaboration, for example, designing schedules with the necessary slots to allow teachers to share, discuss and plan their teaching together. In addition, it seems to be crucial for teachers to become aware of the research-evidenced benefits that this threelevel coordination among teachers of the mother tongue, the language of the CLIL programme, and content teachers may bring about, and not just simply base their future actions on intuitions. A further element highlighted is the necessity to redefine their roles and functions when working in a coordinated way, specifically when it comes to reaching a consensus on methodological issues and evaluation practices. Finally, CLIL teachers would welcome recognition for their involvement in the programme. Administrators need to incentivise the extra amount of work that putting coordination into practice entails; otherwise, there is a serious risk of withdrawal on the part of the teachers or, unfortunately, a depletion of the quality of teaching. These are dimensions which require further investigation in order to gain insight into the challenges and benefits of implementing a structure of collaboration in CLIL.

Considering the limitations of this study, it has to be noted that the focus is teachers' beliefs and opinions, in particular, tearchers' views on their role and performance in CLIL, and the potential of coordination and collaboration as a means to achieve tangible benefits. Although these opinions are essential to understand how teaching is conceived and, ultimately, practised, the results obtained need to be complemented with further investigations on the outcomes deriving from building this structure of collaboration. 
ANALYSING TEACHERS' ROLES REGARDING CROSS-CURRICULAR COORDINATION IN CONTENT ...

\section{REFERENCES}

Arnold, J. 2011. "El dominio afectivo en la enseñanza bilingüe" [The affective domain in bilingual education]. Implicaciones de la enseñanza bilingüe en centros educativos [Implications of bilingual education in schools]. Ed. S. Casal. Seville: Aljibe. 37-48.

Baetens-Beardsmore, H. 2009. "Language promotion by European supra-national institutions". Bilingual Education in the 21 Century: A Global Perspective. O. García (main author). Hoboken, N. J.: Wiley-Blackwell. Part III, Chap. 9, 197-217.

Berton, G. 2008. "Tasks, learning activities and oral production skills in CLIL classrooms". CLIL e l'Appredimento delle lingue. Le sfide del nuovo ambiente di apprendimento [CLIL and the teaching of languages. The challenge of a new teaching environment]. Ed. M.C. Coonan. Venezia: University Ca' Foscari, Venezia. 143-151.

Bonnet, A. 2012. "Towards an evidence base for CLIL: How to integrate qualitative and quantitative as well as process, product and participant perspectives in CLIL Research". International CLIL Research Journal 1 (4): 66-78.

Borg, S. 2001. "Self-perception and practice in teaching grammar". ELT Journal 55 (1): 21-29.

Borg, S. 2006. Teacher Cognition and Language Education: Research and Practice. London: Continuum.

Bruton, A. 2011. "Are the differences between CLIL and non-CLIL groups in Andalusia due to CLIL? A reply to Lorenzo, Casal and Moore (2010)". Applied Linguistics 32 (2): 236-241.

Bruton, A. 2013. "CLIL: some of the reasons why... and why not". System 41: 587-597.

Bustos, B. 2001. "Bilingual education teachers' beliefs and their relation to selfreported practices". Bilingual Research Journal 25 (3): 275-299.

Cenoz, J. 2015. "Content-based instruction and content and language integrated learning: the same or different?" Language, Culture and Curriculum 28: 8-24.

Cenoz, J., Genesee, F. and D. Gorter. 2013. "Critical analysis of CLIL: taking stock and looking forward". Applied Linguistics (advance access): 1-21. <http:// applij.oxofrdjournals.org/>. Accessed on 12 February 2014.

Coonan, C. M. 2007. "Insider views of the CLIL class through teacher selfobservation-introspection2. International Journal of Bilingual Education and Bilingualism 10 (5): 625-646.

Coonan, C. M. 2012. "Affect and motivation in CLIL". Quality interfaces: examining evidence and exploring solutions in CLIL. Eds. D. Marsh and O. Meyer. Eichstätt: Eichstätt Academic Press. 52-65. 
Costa, F. and L. D’Angelo. 2011. "CLIL: A suit for all seasons". Latin American Journal of Content and Language Integrated Learning 4 (1): 1-13.

Coyle, D. 2013. "Listening to learners: an investigation into 'successful learning' across CLIL contexts". International Journal of Bilingual Education and Bilingualism 16 (3): 244-266.

Coyle, D. 2015. "Strengthening integrated learning: Towards a new era for pluriliteracies and intercultural learning". Latin American Journal of Content and Language Integrated Learning 8 (2): 84-103. http://doi.org/10.5294/ laclil.2015.8.2.2.

Coyle, D., Holmes, B. and L. King. 2009. Towards an integrated curriculum - CLIL national statement and guidelines. London: The Languages Company.

Coyle, D., Hood, P. and D. Marsh. 2010. CLIL: Content and Language Integrated Learning. Cambridge: Cambridge University Press.

Creese, A. 2010. "Content-focused classrooms and learning English: how teachers collaborate". Theory Into Practice 9 (2): 99-105.

Cummins, J. 1984. Bilingualism and special education. Clevedon: Multilingual Matters.

Cummins, J. 2008. "Teaching for transfer: challenging the two solitudes assumption in bilingual education". Encyclopedia of Language and Education, 5, Bilingual Education. Eds. J. Cummins and N. Hornberger. New York: Springer Science and Business Media LLC. 65-75.

Dale, L., van der Es, W. and R. Tanner. 2010. CLIL skills. Postbus: University of Leiden.

D'Angelo, L. and E. García. 2012. "The personal and professional profile of the CLIL subject teacher: A research study". Quality interfaces: examining evidence and exploring solutions in CLIL. Eds. D. Marsh and O. Meyer. Eichstaett: Eichstaett Academic Press. 66-77.

Davison, C. 2006. "Collaboration between ESL and content teachers: how do we know we are doing it right?" International Journal of Bilingual Education and Bilingualism 9 (4): 454-475.

Dobson, A., Pérez, M. and R. Johnstone. 2010. Bilingual education project (Spain): evaluation report. Madrid: Ministerio de Educación-British Council.

Frigols, M. J. 2008. "CLIL Implementation in Spain: an approach to different models". CLIL e l'apprendimento delle lingue. Le sfide del nuovo ambiente di apprendimento [CLIL and the teaching of languages. The challenge of a new teaching environment]. Ed. C.M. Coonan. Venice: Libreria Editrice Cafoscarina. 221-232. 
ANALYSING TEACHERS' ROLES REGARDING CROSS-CURRICULAR COORDINATION IN CONTENT ...

Graaff, R., Koopman, G. J. and R. Tanner. 2012. "Integrated opportunities for subject and language learning. Implementing a rubric for cross-curricular learning activities". Quality Interfaces: Examining Evidence and Exploring Solutions in CLIL. Eds. D. Marsh and O. Meyer. Eichstaett: Eichstaett Academic Press. 154-173.

Halbach, A. 2009. "The primary school teacher and the challenges of bilingual education". CLIL across educational levels: experiences from primary, secondary and tertiary contexts. Eds. E. Dafouz and M. Guerrini. Madrid: Richmond Publishing. 19-26.

Hargreaves, A. 1994. "Collaboration and contrived collegiality: cup of comfort or poisoned chalice?" Changing Teachers, Changing Times. Ed. A. Hargreaves. London: Cassell. 186-211.

Hüttner, J., Dalton-Puffer, C. and U. Smit. 2013. "The power of beliefs: lay theories and their influence on the implementation of CLIL programmes". International Journal of Bilingual Education and Bilingualism 16 (3): 267-284.

Infante, D., Benvenuto, G. and E. Lastrucci. 2009. "The effects of CLIL from the perspective of experienced teachers". CLIL Perspectives from the Field. Eds. D. Marsh, P. Mehisto, D. Wolff, R. Aliaga, T. Asikainen, M. J. Frigols, S. Hughes, and G. Langé. Jyväskylä: University of Jyväskylä. 156-163.

Jexenflicker, S. and C. Dalton-Puffer. 2010. "The CLIL differential: comparing the writing of CLIL and non-CLIL students in higher colleges of technology". Language use and language learning in CLIL classrooms. Eds. C. Dalton-Puffer, T. Nikula, and U. Smit. Amsterdam/Philadelphia: John Benjamins Publishing Company. 169-189.

Junta de Andalucía. 2005. Plan to Promote Plurilingualism. A language policy for Andalusian society. Seville, Spain: Junta de Andalucía, Consejería de Educación.

Lasagabaster, D. 2008. "Foreign language competence in Content and Language Integrated courses", The Open Applied Linguistics Journal (I): 31-42.

Lázaro, A. and P. García-Mayo. 2012. "L1 use and morphosyntactic development in the oral production of EFL learners in a CLIL context". International Review of Applied Linguistics, 50, 2, 135-160.

Laupenmühlen, J. 2012. "Making the most of L1 in CL(1+2)IL". Quality interfaces: examining evidence and exploring solutions in CLIL. Eds. D. Marsh and O. Meyer. Eichstaett: Eichstaett Academic Press. 236-250.

Lo, Y.-Y. 2015. "A glimpse into the effectiveness of L2-content cross-curricular collaboration in content-based instruction programmes". International Journal of Bilingual Education and Bilingualism 18 (4): 443-462. 
Lo, Y.-Y. and V. A. Murphy. 2010. "Vocabulary knowledge and growth in immersion and regular language-learning programmes in Hong Kong". Language and Education 4: 215-238.

Lorenzo, F. 2013. "Genre-based curricula: multilingual academic literacy in content and language integrated learning". International Journal of Bilingual Education and Bilingualism 16 (3): 375-388.

Lorenzo, F., Casal, S. and P. Moore. 2009. "The effects of Content and Language Integrated Learning in European education: key findings from the Andalusian bilingual sections evaluation project”. Applied Linguistics 31 (3): 418-442.

Lorenzo, F. and P. Moore. 2010. "On the natural emergence of language structures in CLIL: towards a theory of European educational bilingualism". Language use and language learning in CLIL classrooms. Eds. C. Dalton-Puffer, T. Nikula, and U. Smit. Amsterdan: John Benjamins. 23-38.

Lorenzo, F., Trujillo, F. and J. M. Vez. 2011. Educación bilingüe: integración de contenidos y segundas lenguas [Bilingual education: integration of content and second languages]. Madrid: Síntesis.

Lorenzo, F. and L. Rodríguez. 2014. "Onset and expansion of L2 cognitive academic language proficiency in bilingual settings: CALP in CLIL". System 47: 64-72.

Mackey, A. and S. M. Gass. 2005. Second Language Research. Methodology and Design. Mahwah, NJ: Lawrence Erlbaum Associates.

Madrid, D. 2011. "Monolingual and bilingual students' competence in social sciences". Studies in Bilingual Education. Eds. D. Madrid and S. Hughes. Bern: Peter Lang. 195-221.

Marsh, D. 2007. "Language awareness and CLIL". Encyclopedia of language and education. Knowledge about language, 2nd edition, Volume 6. Eds. J. Cenoz and N. Honrberger. New York: Springer Science and Business Media LLC. 236-246.

Marsh, D. 2009. Study of the contribution of multilingualism to creativity. Final Report. Public Services Contract EACEA/2007/3995/2. Brussels: European Commission.

Marsh, D. 2013. The CLIL trajectory: educational innovation for the 21st century iGeneration. Córdoba: University of Cordoba Academic Press.

Mehisto, P. 2009. "Managing multilingual education: structuring stakeholder dialogue and collaboration". Aplicaciones didácticas para la enseñanza de lengua y contenidos (AICLE/CLIL/ÉMILE) [Didactic applications for content and language integrated learning (AICLE/CLIL/ÉMILE)]. Eds. V. Pavón and J. Ávila. Sevilla: Consejería de Educación de la Junta de Andalucía-Universidad de Córdoba. 9-27. 
ANALYSING TEACHERS' ROLES REGARDING CROSS-CURRICULAR COORDINATION IN CONTENT ...

Mehisto, P. 2012. Excellence in Bilingual Education: A Guide for School Principals. Cambridge: Cambridge University Press.

Mehisto, P., Marsh, D. and M. J. Frigols. 2008. Uncovering CLIL. London: MacMillan.

Mehisto, P. and F. Genesee, eds. 2015. Building Bilingual Education Systems: Forces, Mechanisms and Counterweights. Cambridge: Cambridge University Press.

Méndez García, M. C. 2013. "The Intercultural turn brought about by the implementation of CLIL programmes in Spanish monolingual areas: a case study of Andalusian primary and secondary schools". The Language Learning Journal 1 (5): 268-283.

Méndez García, M. C. and V. Pavón. 2012. "Investigating the coexistence of the mother tongue and the foreign language through teacher collaboration in CLIL contexts: perceptions and practice of the teachers involved in the Plurilingual Programme in Andalusia”. International Journal of Bilingual Education and Bilingualism 15 (5): 574-592.

Merisuo-Storm, T. 2007. "Pupils' attitudes towards foreign language learning and the development of literacy skills in bilingual education". Teaching Teacher Education 23 (2): 226-235.

Meyer, O. 2010. "Towards quality-CLIL: successful planning and teaching strategies". Pulso 33: 11-29.

Meyer, O., Coyle, D., Halbach, A., Schuck, K. and T. Ting. 2015. "A pluriliteracies approach to content and language integrated learning - mapping learner progressions in knowledge construction and meaning-making". Language, Culture and Curriculum 28 (1): 41-57. http://doi.org/10.1080/07908318.2014. 1000924.

Moliner, M. 2013. "The effects of CLIL from the perspective of in-service teachers in Salamanca (Castilla y León, Spain)”. Educaçao y Formaçao 8: 200-217.

Musanti, S. I. and L. P. Pence. 2010. "Collaboration and teacher development: unpacking resistance, constructing knowledge and navigating identities". Teacher Education Quarterly 37 (1): 73-89.

Pavón, V., Ávila, J., Gallego, A. and R. Espejo. 2014. "Strategic and organisational considerations in planning Content and Language Integrated Learning: a study on the coordination between content and language teachers". International Journal of Bilingual Education and Bilingualism 18 (4): 409-425.

Pavón, V. and M. Ellison. 2013. "Examining teacher roles and competences in Content and Language Integrated Learning (CLIL)". Linguarum Arena 4: 65-78.

Pavón, V. and F. Rubio. 2010. "Teachers' concerns about the introduction of CLIL programmes". Porta Linguarum 14: 45-58. 
Pena, C. and M. D. Porto. 2008. "Teacher beliefs in a CLIL education project". Porta Linguarum 8 (2): 151-161.

Ramos Ordóñez, M. C. and V. Pavón. 2015. "Developing cooperative learning through integrated tasks in Content and Language Integrated Learning". Multidisciplinary Journal of Educational Research 5 (2): 136-166.

Ruiz de Zarobe, Y. 2008. "CLIL and foreign language learning: a longitudinal study in the Basque Country". International CLIL Research Journal 1 (1): 60-73.

Ruiz de Zarobe, Y. 2011. "Which language competencies benefit from CLIL? An insight into applied linguistics research". Content and Foreign Language Integrated Learning. Contributions to Multilingualism in European Contexts. Eds. Y. Ruiz de Zarobe, J. M. Sierra, and F. Gallardo del Puerto. Bern: Peter Lang. 129-153.

Ruiz de Zarobe, Y. 2013. "CLIL implementation: from policy-makers to individual initiatives". International Journal of Bilingual Education and Bilingualism 16 (3): 231-243.

Tan, M. 2011. "Mathematics and science teachers' beliefs and practices regarding the teaching of language in content learning". Language Teaching Research 15 (3): 325-342.

Travé, G. 2013. "A study on primary school teachers' representations about bilingual teaching. Revista de Educación 361: 379-402.

Viebrock, B. 2012. "The situation in the CLIL classroom is quite different -or is it? teachers' mindsets, methodological competences and teaching habits". Quality interfaces: examining evidence and exploring solutions in CLIL. Eds. D. Marsh and O. Meyer. Eichstaett: Eichstaett Academic Press. 78-90.

Woods, D. 1996. Teacher cognition in language teaching: beliefs, decision-making, and classroom practice. Cambridge: Cambridge University Press.

Wolff, D. 2012. "The European framework for CLIL teacher education". Synergies 8: $105-116$. 


\section{APPENDIX}

\section{QUESTIONNAIRE FOR TEACHERS}

The following questions are meant to be a starting point for pondering on some crucial aspects for the organisation of the bilingual programme. The objective of the questions is to foster personal reflection based on your own understanding and experience.

\section{Personal information}

1. Age and sex.

2. Years of experience in CLIL bilingual schools.

3. Teaching in Primary or Secondary Schools?

4. In your opinion, are foreign languages necessary for the students' future professional career?

5. Do you think that learning through English will benefit or harm the students' intellectual and academic development?

6. Are you aware of the European policy/recommendations on multilingualism?

7. Are you familiar with different models of bilingual education?

8. Are you aware of the differences between immersion programmes and CLIL?

9. May teaching through a foreign language affect the assimilation of academic content negatively?

10. Is CLIL beneficial for teachers?

11. To what extent does working in a bilingual school influences your personal and professional development?

12. In your opinion, what is more important for teachers, exhibiting a high command of the foreign language or having a solid knowledge of methodology?

13. Is teachers' coordination and collaboration an essential element in CLIL?

14. Are teachers in general used to collaborating?

15. In which areas would collaboration be more relevant? 
16. Do you think that content teachers need to collaborate with foreign language teachers?

17. If so, what kind of collaboration needs to be facilitated and implemented?

18. Would it be important for content teachers to collaborate with other content teachers?

19. Would it be necessary for content teachers to deal with common thematic areas?

20. What do you think about the collaboration between language teachers (mother tongue, foreign language used for instruction, and possibly a second foreign language)?

21. Are you aware of the process of language transfer?

22. How much do you know about the characteristics of tandem teaching?

23. How could assessment benefit from constructing collaboration between teachers?

24. Do you think that assessing the language should be a pivotal aspect for content teachers?

25. What is your opinion about using the mother tongue in the bilingual class? 